\title{
Health Hazard Associated with Water and Mosquito Borne Diseases: A Case Study in the Barak Valley Along Silchar Town of Assam, Northeast India
}

\author{
Mohit Kumar ${ }^{*}$, Bhanu Prakash Mishra \\ Department of Environmental Science, Mizoram University, Mizoram, India \\ Email address: \\ mohitkumar255174@gmail.com (M. Kumar), mishrabp111@yahoo.com (B. P. Mishra) \\ ${ }^{*}$ Corresponding author
}

\section{To cite this article:}

Mohit Kumar, Bhanu Prakash Mishra. Health Hazard Associated with Water and Mosquito Borne Diseases: A Case Study in the Barak Valley Along Silchar Town of Assam, Northeast India. Journal of Health and Environmental Research. Vol. 7, No. 2, 2021, pp. $105-111$.

doi: 10.11648/j.jher.20210702.14

Received: April 6, 2021; Accepted: April 22, 2021; Published: April 30, 2021

\begin{abstract}
Objective (s): The current investigation has been carried out to determine the health hazard caused by water and mosquito borne diseases in the valley of river Barak along Silchar city (Assam); which has been recognized as a vulnerable area in terms of various kinds of hazards. Materials and Methods: In this study, the data analysis for several water and mosquito borne diseases viz., Acute diarrhoea, Bacillary dysentery, Enteric fever and Malaria has been accomplished proficiently on monthly as well as annually interval for a period of 5 successive years (i.e. 2015 to 2019). Results: The data demonstrates that the concentration of patients affected by Acute diarrhoea and Malaria was found to be decreased irrespective of years. On the other hand, in the cases of Bacillary dysentery and Enteric fever, the concentration of patients has been observed to be continue increasing within due course of the five years. Conclusion: On the basis of the results, It can be argued that Bacillary Dysentery and Enteric fever illustrated the similar and increasing trend; On the contrary, Acute diarrhoea and Malaria has been showed the drastically decreasing trend throughout the study period i.e., from 2015 to 2019 .
\end{abstract}

Keywords: Human Health, Acute Diarrhoea, Enteric Fever, Bacillary Dysentery, Malaria

\section{Introduction}

The North-eastern region of India consists of the eight states namely, Assam, Manipur, Mizoram, Meghalaya, Arunachal Pradesh, Nagaland, Tripura and Sikkim; which expends over the area of about 262,179 square kilometres [1]. Among of the above, Assam is called as the gateway for north-eastern region of the country and also known as the "Land of red river and the blue hills" [2]. During the recent decades, population explosion and unplanned developmental activities for settlement in vulnerable areas have increased risk in connection with several natural and anthropogenic hazards. The Barak is an important river of North-eastern region of the country as well as of Assam in particular. Its basin spreads within longitudes $89^{\circ} 50^{\prime} \mathrm{E}$ to $94^{\circ} 0^{\prime} \mathrm{E}$ and latitudes $22^{\circ} 44^{\prime} \mathrm{N}$ to $25^{\circ} 58^{\prime} \mathrm{N}$ along with maximal length and width of 460 kilometres and 350 kilometres respectively. The valley of Barak has a width of $25-30 \mathrm{~km}$ and it expands over an area of 6,962 square kilometres accounting for around 9 percent of the total geographical area of the state of Assam [3]. The surrounding mountains bordering the valley are subject to excessive precipitation [4].

The sickness caused by waterborne diseases arises when pathogens arrive into the supply of water in lack of detection and are then ingested, either via drinking water or through contaminated food, by uncircumcised persons [5]. In the region of South Asia, It is evaluated that around 23 percent of population (about 400 millions of person) surviving in high level risk conditions in relation to waterborne diseases $[6,7]$. Across to the world, the mosquito borne diseases causes to the great figures in terms of worldwide mortality and morbidity, particularly influencing to the youth adults and children on assessing the regional areas of malaria [8].

Malaria is in the category of mosquito borne infectious disease due to parasitic protozoa of genus plasmodium which spread by female Anopheles mosquitoes [9]. This disease has 
long plagued several countries around the globe. As per the newest evaluation by World Health Organization, globally there were around 214 million new cases of malaria in the year of 2015 (range 149-303 million) [10, 11].

Bacillary dysentery is the enteric infectious disease which caused by Shigella spp [12]. It is dominantly spread by the fecal oral route through contaminated water, food, or contact of person to person [12-17]. Globally, there was around 164.7 million persons annually documented as confirmed cases of Shigella incidences as well as about 1.1 million passing in developing nations [18].

The Enteric fever which is also known as Typhoid fever [19]; is a waterborne infection which can prevalence by dairy belongings and shellfish, and less commonly through coordinate contact with faeces, or other body releases [20, 21]. The dominant burden of this disease is found among the low-income nations where incapable or weak services of water and sanitation. It is evaluated that globally around 27 million new infections and more than 200000 passings have been caused by enteric fever every year [22-24].

The acute diarrhoea can be explained as faeces with increasing water content, volume, or frequency that remain under 14 days $[25,26]$. Bacteria, viruses and, infrequently, parasites are the infectious causes of this disease [26]. Waterborne diarrheal disease is very grievous, particularly for developing nations, where the outburst happens periodically and are allied with poverty and use of unhealthy water and worse sanitation [27, 28]. As per the joint statement of WHO/UNICEF, every year beyond 1.5 million children below five continue to die caused by acute diarrhoea [29].

By virtue of the above, present research has been accomplished with an objective to analyse the health hazard on account of water and mosquito borne diseases in the Barak valley along the city of Silchar, Assam, NE India.

\section{Material and Methods}

\subsection{Description of Study Area}

Apart from being a major administrative town, Silchar has obtained the significant weightage in terms of the trade and commerce, educational and social activities in the region of Barak valley. The municipal region expend within $24^{\circ} 47^{\prime} 47^{\prime \prime}$ to $24^{\circ} 50^{\prime} 52.5^{\prime \prime}$ North latitudes and $92^{\circ} 46^{\prime} 16.9 "$ to
92 49'33.4" East longitude [30]. The city has the noteworthy majesty in view of the doorway for three districts of Barak valley namely, Cachar, Karimganj and Hailakandi. It is situated at around 35 metre above mean sea level (msl) and mostly on the southern bank of river Barak.

Silchar is the most densely populated town of southern Assam in the valley of Barak. The graph of population of the city hiked by 1.42 lakhs and 1.72 lakhs in the year 2001 and 2011 respectively, which reflecting an average increasing rate of 2.3 percent and 2.1 percent respectively [31]. The city is also known as the nourishing centre of tea industries of the Cachar district. In the ancient time, the British emperors used the place as the river port for the purpose of exporting the raw materials and tea. It had its first municipal in the year of 1893 [32].

\subsection{Methods}

The information on water and mosquito borne diseases was procured for the timeframe of 5 consecutive years (i.e. from 2015 to 2019) on weekly basis; and monthly as well as annually values were computed. The concerned data on several water and mosquito borne diseases namely, Bacillary dysentery, Malaria, Enteric fever and Acute diarrhoea have been collected from the Office of the Chief Medical Officer, S. M. Dev Civil Hospital, Silchar, Assam. The information was acquired from aforesaid department computed to estimate the health hazard due to water and mosquito borne diseases in the valley of river Barak along Silchar town, Assam, Northeast India.

\section{Results and Discussion}

The findings of current study with the aim of investigating health hazard associated with water and mosquito borne diseases in Barak valley along Silchar city of Assam can be shown as follows.

During 2015, the number of patients affected by Acute diarrhoea, Enteric fever and Malaria ranged between 868 (in the month of October) to 1385 (in the month of July), 27 (in the month of March) to 81 (in the month of October) and 65 (in the month of January) to 133 (in the month of September), respectively. Bacillary dysentery was not reported so far (Table 1).

Table 1. Number of patients affected by Acute diarrhoea, Bacillary dysentery, Enteric fever and Malaria during 2015.

\begin{tabular}{|c|c|c|c|c|}
\hline \multirow{2}{*}{ Months } & \multicolumn{4}{|c|}{ Water and Mosquito borne diseases } \\
\hline & Acute diarrhoea & Bacillary dysentery & Enteric fever & Malaria \\
\hline January & 1000 & 0 & 33 & 65 \\
\hline February & 1028 & 0 & 33 & 95 \\
\hline March & 915 & 0 & 27 & 102 \\
\hline April & 1312 & 0 & 69 & 102 \\
\hline May & 1236 & 0 & 54 & 130 \\
\hline June & 1205 & 0 & 48 & 90 \\
\hline July & 1385 & 0 & 59 & 95 \\
\hline August & 992 & 0 & 71 & 125 \\
\hline September & 1257 & 0 & 47 & 133 \\
\hline October & 868 & 0 & 81 & 106 \\
\hline November & 1111 & 0 & 75 & 109 \\
\hline December & 1370 & 0 & 77 & 67 \\
\hline
\end{tabular}


Similarly, during 2016, the minimum and maximum number of patients affected by Acute diarrhoeal disease was 701 (in the month of December) to 1485 (in the month of March) respectively; Bacillary dysentery up to 10 (in the month of April); Enteric fever was 42 (in the month of April) to 136 (in the month of June) respectively; Malaria was observed as 55 (in the month of December) to 158 (in the month of June) respectively (Table 2).

Table 2. Number of patients affected by Acute diarrhoea, Bacillary dysentery, Enteric fever and Malaria during 2016.

\begin{tabular}{lllll}
\hline \multirow{2}{*}{ Months } & \multicolumn{2}{l}{ Water and Mosquito borne diseases } & Malaria \\
\cline { 2 - 5 } & Acute diarrhoea & Bacillary dysentery & Enteric fever & 68 \\
\hline January & 975 & 0 & 49 & 58 \\
February & 973 & 0 & 59 & 100 \\
March & 1485 & 0 & 75 & 91 \\
April & 1113 & 10 & 42 & 88 \\
May & 1136 & 0 & 66 & 158 \\
June & 1423 & 0 & 136 & 120 \\
July & 1039 & 0 & 76 & 120 \\
August & 1434 & 0 & 110 & 95 \\
September & 1125 & 0 & 78 & 143 \\
October & 1150 & 0 & 118 & 142 \\
November & 1166 & 0 & 111 & 55 \\
December & 701 & 66 & \\
\hline
\end{tabular}

In addition, during 2017, the number of persons affected by Acute diarrhoea, Bacillary dysentery, Enteric fever and Malaria ranged between 556 (in the month of February) to 1330 (in the month of August), up to 7 (in the month of
February), 54 (in the month of February) to 166 (in the month of July) and 69 (in the month of February) to 166 (in the month of July), respectively (Table 3 ).

Table 3. Number of patients affected by Acute diarrhoea, Bacillary dysentery, Enteric fever and Malaria during 2017.

\begin{tabular}{|c|c|c|c|c|}
\hline \multirow{2}{*}{ Months } & \multicolumn{4}{|c|}{ Water and Mosquito borne diseases } \\
\hline & Acute diarrhoea & Bacillary dysentery & Enteric fever & Malaria \\
\hline January & 590 & 4 & 62 & 77 \\
\hline February & 556 & 7 & 54 & 69 \\
\hline March & 932 & 5 & 69 & 98 \\
\hline April & 966 & 0 & 64 & 71 \\
\hline May & 1324 & 0 & 132 & 142 \\
\hline June & 1074 & 1 & 156 & 145 \\
\hline August & 1330 & 0 & 134 & 116 \\
\hline September & 1045 & 0 & 139 & 93 \\
\hline October & 1128 & 0 & 126 & 131 \\
\hline November & 1280 & 6 & 127 & 107 \\
\hline December & 921 & 1 & 102 & 99 \\
\hline
\end{tabular}

During 2018, the minimum and maximum number of patients affected by Acute diarrhoeal disease was 676 (in the month of December) to 1445 (in the month of August) respectively; Bacillary dysentery was 2 (in the month of January) to 8 (in the month of July) respectively; Enteric fever was 79 (in the month of January) to 247 (in the month of October) respectively; Malaria was observed by 60 (in the month of April) to 145 (in the month of October) respectively (Table 4).

Table 4. Number of patients affected by Acute diarrhoea, Bacillary dysentery, Enteric fever and Malaria during 2018.

\begin{tabular}{|c|c|c|c|c|}
\hline \multirow{2}{*}{ Months } & \multicolumn{4}{|c|}{ Water and Mosquito borne diseases } \\
\hline & Acute diarrhoea & Bacillary dysentery & Enteric fever & Malaria \\
\hline January & 1151 & 2 & 79 & 80 \\
\hline February & 1049 & 8 & 90 & 90 \\
\hline March & 940 & 3 & 110 & 91 \\
\hline April & 1034 & 3 & 154 & 60 \\
\hline May & 1376 & 5 & 201 & 95 \\
\hline June & 1057 & 7 & 159 & 103 \\
\hline July & 1168 & 8 & 232 & 93 \\
\hline August & 1445 & 8 & 213 & 77 \\
\hline September & 1098 & 5 & 199 & 76 \\
\hline October & 946 & 2 & 247 & 145 \\
\hline November & 800 & 2 & 195 & 81 \\
\hline December & 676 & 6 & 147 & 79 \\
\hline
\end{tabular}


Moreover, during 2019, the number of patients affected by Acute diarrhoea ranged between 589 (in the month of February) to 1306 (in the month of July), Bacillary dysentery between 1 (in the month of December) to 11 (in the month of
July), Enteric fever between 26 (in the month of December) to 436 (in the month of July) and Malaria between 26 (in the month of December) to 170 (in the month of July) (Table 5).

Table 5. Number of patients affected by Acute diarrhoea, Bacillary dysentery, Enteric fever and Malaria during 2019.

\begin{tabular}{|c|c|c|c|c|}
\hline \multirow{2}{*}{ Months } & \multicolumn{4}{|c|}{ Water and Mosquito borne diseases } \\
\hline & Acute diarrhoea & Bacillary dysentery & Enteric fever & Malaria \\
\hline January & 886 & 6 & 136 & 77 \\
\hline February & 589 & 4 & 213 & 86 \\
\hline March & 662 & 6 & 222 & 52 \\
\hline April & 712 & 6 & 150 & 66 \\
\hline May & 1292 & 7 & 163 & 125 \\
\hline June & 1211 & 7 & 184 & 60 \\
\hline August & 940 & 5 & 248 & 67 \\
\hline September & 897 & 4 & 121 & 76 \\
\hline October & 1163 & 6 & 132 & 48 \\
\hline November & 820 & 2 & 93 & 44 \\
\hline December & 751 & 1 & 26 & 26 \\
\hline
\end{tabular}

The graphical representation of water and mosquito borne diseases i.e., Acute diarrhoea, Bacillary dysentery, Enteric fever and Malaria throughout study period (2015-19) are presented in figures 1 to 4 respectively.

In case of Acute diarrhoea, the total number of patients affected was decreased from 2015 to 2019, with exception during 2016 and 2018 reflecting minor growth. A sharp decrement was noticed during the year of 2019 showing much less numbers than 2018. It was observed that the trendline (linear) shows the downward direction (Figure 1). Therefore, the trend reflects that the concentration of patients affected by Acute diarrhoea has been decreased due course of five year time.

There is an increasing trend has been observed in case of Bacillary dysentery as the number of patients was continue increased from 2015 to 2019 with a major growth during the year of 2018. It was detected that the trend-line shows the upward direction (Figure 2). Therefore, the trend reflects that the concentration of patients affected by Bacillary dysentery is increasing due course of time.

Similarly, the total number of patients affected by Enteric fever was continue increased from 2015 to 2019 and follows the trend as observed in case of Bacillary dysentery. The trend-line shows the upward direction (Figure 3). Therefore, the trend reflects that the concentration of patients affected by Enteric fever is increasing due course of time.

In addition, the total number of patients affected by Malaria was decreased from 2015 to 2019, with exception during 2016 and 2017 reflecting minor growth. The large scale decrement was noticed during the year of 2018 and 2019. It was observed that the trend-line shows the downward direction (Figure 4). Therefore, the trend reflects that the concentration of patients affected by Malaria has been decreased due course of five years.

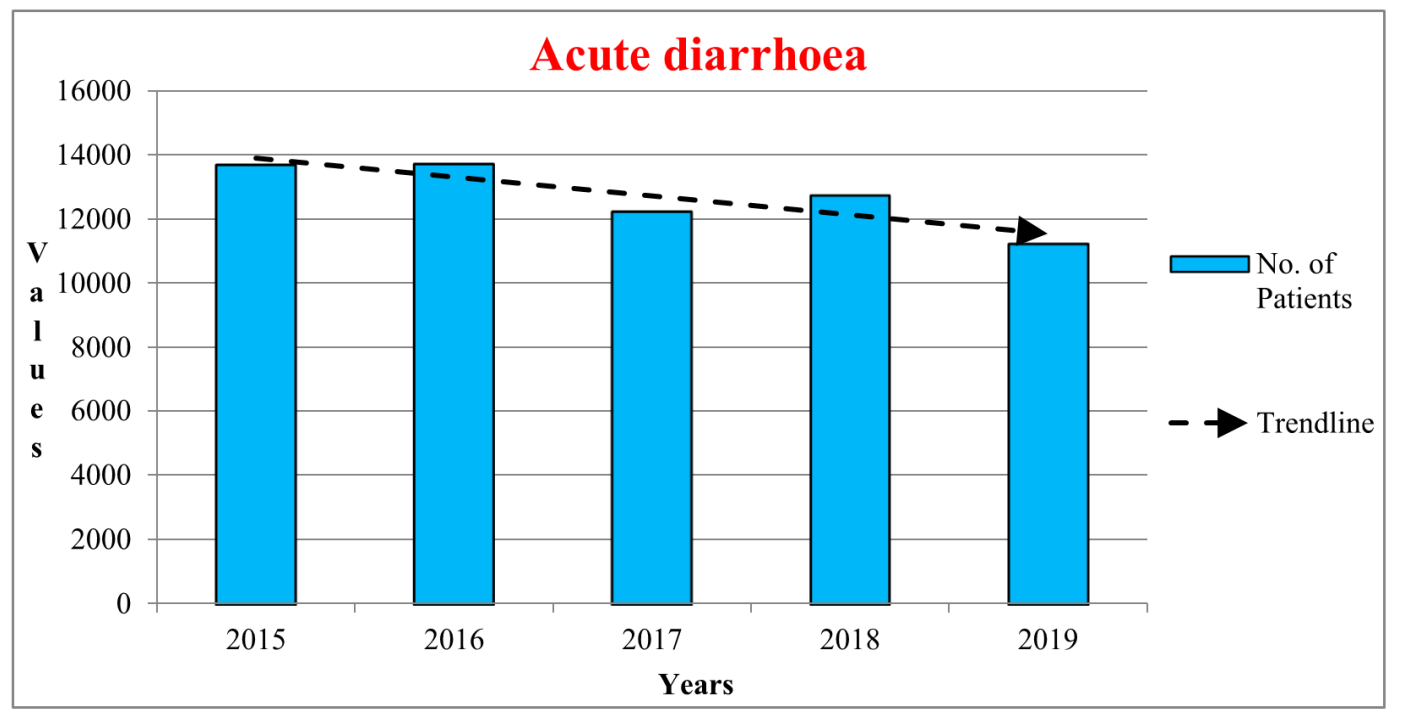

Figure 1. Number of patients affected by Acute diarrhoea during 2015-2019. 




Figure 2. Number of patients affected by Bacillary dysentery during 2015-2019.

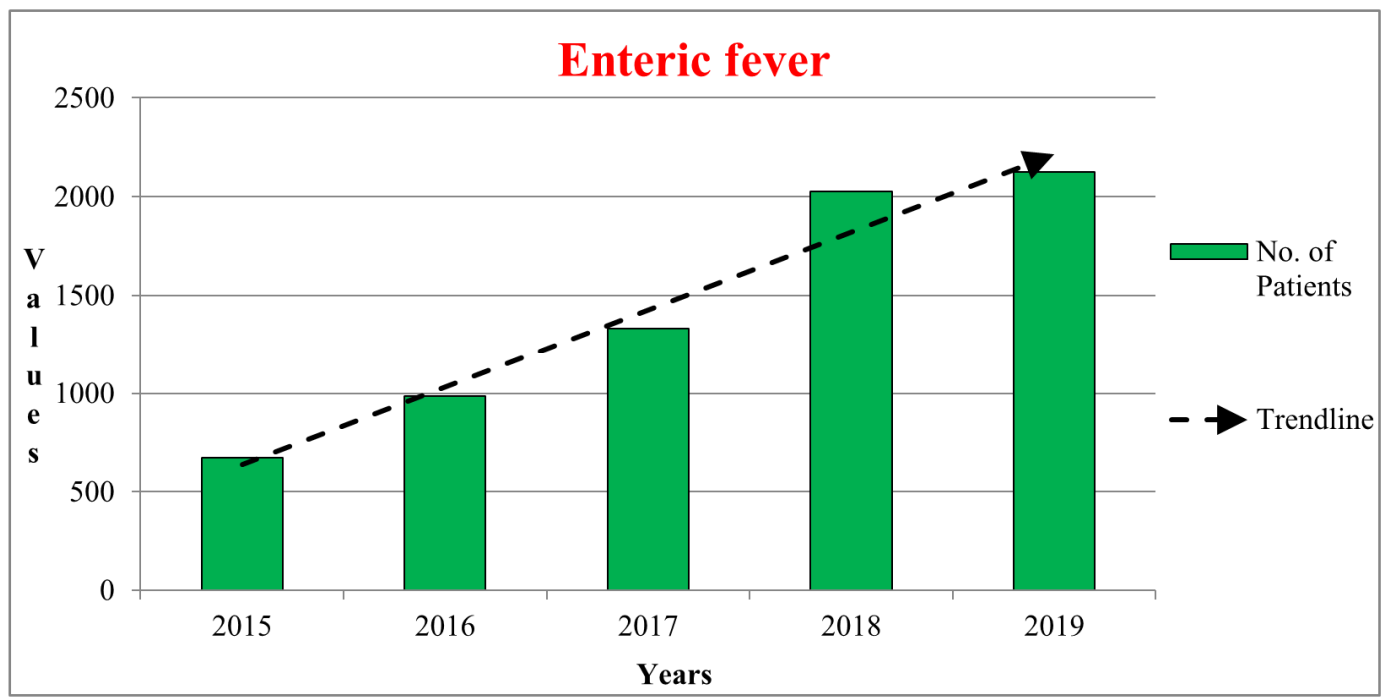

Figure 3. Number of patients affected by Enteric fever during 2015-2019.

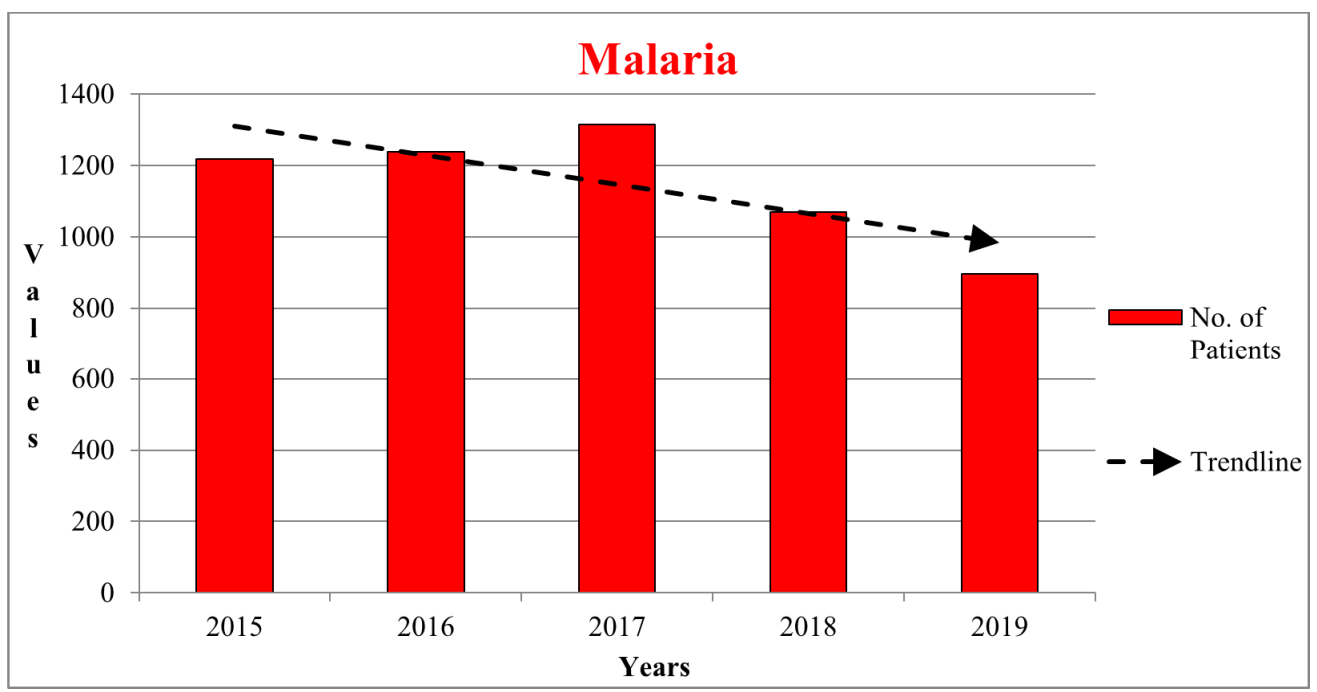

Figure 4. Number of patients affected by Malaria during 2015-2019. 
The overall scenario reflects that the concentration of patients affected by Acute diarrhoea and Malaria is decreasing from 2015 to 2019. Whereas, a reverse trend in results has been established for Bacillary dysentery and Enteric fever as the concentration of patients were found to be continue increasing across study time frame. Mouton et al. (2017) carried out the research on typhoid enteric fever [19]; An extensive research was conducted on Acute diarrhea by Barr and Smith (2014) [26]; Hagenlocher and Castro (2015) studies on malaria risk and vulnerability in the country of Tanzania [33]; Rehman et al. (2011) carried out the research on Bacillary dysentery [34]; Kothari et al. (2008) carried out investigation on burden of enteric fever [35]; An extensive research was conducted on the treatment of acute diarrhoea by Caramia et al. (2015) [36]; Sharma et al. (2021) worked on the socio-economic factors of malaria in Mandla district of Madhya Pradesh in India [37]. The findings of current investigation are in conformity with the researches of aforesaid scientists.

\section{Conclusion}

The present research was designed to determine the health hazard caused by water and mosquito borne diseases (Acute diarrhoea, Bacillary dysentery, Enteric fever and Malaria) in the Barak valley along Silchar city of Assam, Northeast India. The appropriate information and data were procured from the concerned department for the period of 5 successive years (i.e. 2015 to 2019) for computation purpose. The results depict the decreasing trend in the cases of Acute diarrhoea and Malaria as the concentration of patients was found to decreased throughout study period. On the contrary, a similar and increasing trend was observed in the cases of Bacillary dysentery and Enteric fever with continue increasing the concentration of patients within due course of five years. The findings of current research may be a base line for further studies to investigating health hazard as a consequence of water and mosquito borne diseases in the valley of Barak River along Silchar town, Assam (India).

\section{Conflict of Interest Statement}

The authors declare that they have no competing interests.

\section{Acknowledgements}

The authors are thankful to all the staff members of SM Dev Civil Hospital, Silchar (Assam) for providing the relevant information in terms of water and mosquito borne diseases. The authors acknowledge the Department of Environmental Science, Mizoram University (India) for providing essential resources to complete current research satisfactorily and efficiently. We would also like to extend the thank to the anonymous reviewers who contributed substantially to the quality of this paper.

\section{References}

[1] Anonymous. River flooding and erosion in Northeast India. Northwest Hydraulics Consultants (NHC), Edmonton, Alberta, Canada; 2006.

[2] Prasad E. Situation analysis on floods in East and Northeast India. In: Prasad E, Mukherjee N, editors. Situation Analysis on Floods and Flood Management. Asia Regional Office, Bangkok: IUCN, International Union for Conservation of Nature; 2014. p. 9-53.

[3] Bora AK. Drainage and Flood. In: Bhagabati AK, Kar BK, Bora AK, editors. Geography of Assam. 2nd ed. New Delhi: Rajesh publications; 2002.

[4] Thakkar H. What, who, how and when of Experiencing Floods as a Disaster. South Asia Network on Dams, Rivers \& People, Delhi; 2006.

[5] Mansour SA. Impact of climate change on air and water borne diseases. Air Water Borne Diseases 2013; 3 (1): 1-2.

[6] Mogasale V, Maskery B, Ochiai RL, Lee JS, Mogasale VV, Ramani E, et al. Burden of typhoid fever in low-income and middle-income countries: a systematic literature-based update with risk-factor adjustment. Lancet Glob Health 2014; (2): e570-580.

[7] Kaljee LM, Pach A, Garrett D, Bajracharya D, Karki K, Khan I. Social and economic burden associated with typhoid fever in Kathmandu and surrounding areas: A qualitative study. The Journal of Infectious Diseases 2018; 218 (S4): S243-S249.

[8] Nanjesh KS, Hegde R, Badiger S, Kiran KG. A study of mosquito borne diseases awareness, attitude and practices among the rural population in Karnataka, India. International Journal of Community Medicine and Public Health 2017; 4 (11): 4178-4181.

[9] M'Bra RK, Kone B, Soro DP, N'krumah RTAS, Soro N, Ndione JA, et al. Impact of climate variability on the transmission risk of malaria in northern Co Ãte d'Ivoire. PLOS ONE 2018; 13 (6): 1-15.

[10] WHO. Fact Sheet: World Malaria Report 2015, World Health Organization; 2016.

[11] Kurup R, Deonarine G, Ansari AA. Malaria trend and effect of rainfall and temperature within Regions 7 and 8, Guyana. International Journal of Mosquito Research 2017; 4 (6): 4855 .

[12] Chang Z, Zhang J, Ran L, Sun J, Liu F, Luo L, et al. The changing epidemiology of bacillary dysentery and characteristics of antimicrobial resistance of Shigella isolated in China from 2004-2014. BMC Infectious Diseases 2016; 16: $1-10$.

[13] Nandy S, Dutta S, Ghosh S, Ganai A, Rajahamsan J, Theodore RBJ, et al. Foodborne-associated Shigella sonnei, India, 2009 and 2010. Emerging Infectious Diseases 2011; 17 (11): 20722074.

[14] Nygren BL, Schilling KA, Blanton EM, Silk BJ, Cole DJ, Mintz ED. Foodborne outbreaks of shigellosis in the USA, 1998-2008. Epidemiol Infect 2013; 141 (2): 233-241. 
[15] Bhattacharya SK, Sur D, Mahalanabis D. Public health significance of shigellosis. Indian Pediatrics 2012; 49 (4): 269-270.

[16] Anonymous. Centers for Disease Control and Prevention (CDC). Notes from the field: Outbreak of infections caused by Shigella sonnei with decreased susceptibility to azithromycin - Los Angeles, California, 2012. MMWR Morb Mortal Wkly Rep; 62 (9): 171; 2013.

[17] He F, Han K, Liu L, Sun W, Zhang L, Zhu B, et al. Shigellosis outbreak associated with contaminated well water in a rural elementary school: Sichuan Province, China, June 7-16, 2009. PLOS ONE 2012; 7 (10): e47239.

[18] Kotloff KL, Winickoff JP, Ivanoff B, Clemens JD, Swerdlow DL, Sansonetti PJ, et al. Global burden of Shigella infections: implications for vaccine development and implementation of control strategies. Bulletin of the World Health Organization 1999; 77 (8): 651-666.

[19] Mouton F, Ohuoba EI, Evans FM, Desalu I. Typhoid enteric fever - part 1. Update in Anaesthesia 2017; 32: 13-16.

[20] House D, Bishop A, Parry C, Dougan G, Wain J. Typhoid fever: pathogenesis and disease. Current Opinion in Infectious Diseases 2001; 14: 573-578.

[21] Yasin N, Jabeen A, Nisa I, Tasleem U, Khan H, Momin F, et al. A review: Typhoid fever. J Bacteriol Infec Dis 2018; 2 (3): 1-7.

[22] Buckle GC, Walker CLF, Black RE. Typhoid fever and paratyphoid fever: Systematic review to estimate global morbidity and mortality for 2010 . journal of global health 2012; 2 (1): 10401.

[23] Crump JA, Luby SP, Mintz ED. The global burden of typhoid fever. Bulletin of the World Health Organization 2004; 82 (5): 346-353.

[24] Arjyal A, Basnyat B, Nhan HT, Koirala S, Giri A, Joshi N, et al. Gatifl oxacin versus ceftriaxone for uncomplicated enteric fever in Nepal: an open-label, two-centre, randomised controlled trial. Lancet Infect Dis 2016; 1-11.

[25] Guerrant RL, Gilder TV, Steiner TS, Thielman NM, Slutsker L, Tauxe RV, et al. Infectious Diseases Society of America. Practice guidelines for the management of infectious diarrhea. Clin Infect Dis 2001; 32 (3): 331-351.
[26] Barr W, Smith A. Acute diarrhea in adults. American Family Physician 2014; 89 (3): 180-189.

[27] Annonymous. World Health Organization - World Meteorological Organization. Atlas of health and climate. Geneva: WHO, WMO; 2012.

[28] Funari E, Manganelli M, Sinisi L. Impact of climate change on waterborne diseases. ANN IST SUPER SANITA 2012; 48 (4): 473-487.

[29] Anonymous. Clinical management of acute diarrhoea. WHO/UNICEF JOINT STATEMENT; World Health Organization, Geneva / United Nations Children's Fund, New York; 2004.

[30] Kumar M, Mishra BP. Pattern and inter-relationship between climatic variables pertaining to flood hazard impacting river Barak basin along Silchar city, Assam, Northeast India. Disaster Advances 2019; 12 (3): 32-39.

[31] Roy AT, Deb U, Mazumder R. Sustainable Urban Waste Management in Silchar Municipal Area: An Application of Contingent Valuation Method in Cachar District of Assam. International Journal of Humanities and Social Science Invention 2013; 2 (1): 25-33.

[32] Anonymous. City Disaster Management Plan. District Disaster Management Authority, Cachar, Silchar; 2012.

[33] Hagenlocher M, Castro MC. Mapping malaria risk and vulnerability in the United Republic of Tanzania: a spatial explicit model. Population Health Metrics 2015; 13 (2): 1-14.

[34] Rehman RU, Akhtar N, Akram M, Shah PA, Saeed T, Jabeen $\mathrm{Q}$, et al. Bacillary dysentery: A review. Journal of Medicinal Plants Research 2011; 5 (19): 4704-4708.

[35] Kothari A, Pruthi A, Chugh TD. The burden of Enteric fever. J Infect Developing Countries 2008; 2 (4): 253-259.

[36] Caramia G, Silvi S, Verdenelli MC, Coman MM. Treatment of acute diarrhoea: Past and Now. Int J Enteric Pathog 2015; 3 (4): 8-19.

[37] Sharma RK, Rajvanshi H, Bharti PK, Nisar S, Jayswar H, Mishra AK, et al. Socio-economic determinants of malaria in tribal dominated Mandla district enrolled in Malaria Elimination Demonstration Project in Madhya Pradesh. Malaria Journal 2021; 20: 1-13. 